\title{
Originals
}

\section{Evidence of an accelerated B-cell destruction in HLA-Dw3/Dw4 heterozygous children with Type 1 (insulin-dependent) diabetes}

\author{
M. Knip ${ }^{1}$, J. Ilonen ${ }^{2}$, A. Mustonen ${ }^{1}$ and H. K. Åkerblom ${ }^{3}$ \\ 1 Department of Paediatrics, University of Oulu, \\ 2 National Public Health Institute, Oulu, and \\ 3 the Children's Hospital, II Department of Paediatrics, University of Helsinki, Helsinki, Finland
}

Summary. The possible association between residual B-cell function and specific HLA antigens in Type 1 (insulin-dependent) diabetes was studied in a cross-sectional series of 144 diabetic children and adolescents, as well as in a prospective series of 44 newly diagnosed diabetic subjects who were observed for the initial 2 years of their diabetes. In the crosssectional study, the HLA-Dw3/Dw4 heterozygotes had a lower mean serum C-peptide concentration during 1980, $0.03 \pm$ $0.01 \mathrm{nmol} / 1$ (mean $\pm \mathrm{SEM}$ ) vs. $0.09 \pm 0.01 \mathrm{nmol} / 1(p<0.02)$, as well as a lower 24-h urinary C-peptide excretion, $0.27 \pm$ $0.06 \mathrm{nmol} / \mathrm{m}^{2}$ vs. $1.34 \pm 0.19 \mathrm{nmol} / \mathrm{m}^{2}(p<0.05)$, than the other subjects. In addition, the Dw3/Dw4 heterozygotes had a clinical remission of shorter duration, $113 \pm 47$ days vs. $203 \pm$ 22 days $(p<0.05)$, and a higher mean glycosylated haemoglobin level during $1980,14.8 \pm 0.05 \%$ vs. $13.7 \pm 0.2 \%(p<0.05)$, than those without the Dw3/Dw4 combination. In the prospective study the serum C-peptide concentrations were of the same magnitude in the Dw3/Dw4 heterozygotes and the oth- er subjects during the first month. Subsequently the C-peptide concentrations in the subjects with the Dw3/Dw4 combination started to decrease 2 months earlier than in the other subjects. The Dw3/Dw4 children had a significantly lower serum C-peptide concentration at 21 months, $0.01 \pm 0.01 \mathrm{nmol} / 1$ vs. $0.13 \pm 0.02 \mathrm{nmol} / \mathrm{l} \quad(p<0.01)$, and at 24 months, $0.03 \pm$ $0.01 \mathrm{nmol} / 1$ vs. $0.12 \pm 0.02 \mathrm{nmol} / 1(p<0.05)$. Our observations suggest that Dw3/Dw4 heterozygosity is, at least in children, associated with a distinct form of Type 1 diabetes characterized by a rapid B-cell destruction, a clinical remission of short duration and poor metabolic control. This expands the concept of genetic heterogeneity within Type 1 diabetes in childhood, and may have important implications for research on the aetiology, pathogenesis and natural history of the disease.

Key words: Type 1 diabetes, C-peptide, HLA, clinical remission, metabolic control.
HLA studies in subjects with Type 1 (insulin-dependent) diabetes have accumulated considerable evidence for genetic heterogeneity within the disease [1-5]. It appears that there are at least two different susceptibility genes linked to the HLA region. One is associated with HLA-D(R)3 and the other with $-D(R) 4$. The $D(R) 3$ positive form has been reported to be accompanied by the persistence of cytoplasmic islet cell antibodies and the lack of an antibody response to exogenous insulin [6]. The $\mathrm{D}(\mathrm{R}) 4$ positive form seems to be characterized by clinical manifestation at an early age and an exaggerated formation of insulin antibodies. The possible relationship between HLA antigens and residual B cell function in Type 1 diabetes in controversial [7]. Recently Hoogwerf et al. [8] have demonstrated an increased meal-stimulated C-peptide response in HLA-DR4 positive diabetic patients, whereas some other studies have failed to show any correlation between HLA determinants and circulating C-peptide concentrations $[9,10]$.
Since it has been speculated that the high risk antigens in or related to the $\mathrm{D}$ locus may be directly involved in the pathogenesis of pancreatic B cell destruction [5], we decided to study whether there are any associations between endogenous insulin secretion and specific HLA antigens in children and adolescents with Type 1 diabetes.

\section{Subjects and methods}

\section{Subjects}

The study consisted of a cross-sectional as well as a prospective section. The cross-sectional study included 144 HLA-typed children and adolescents ( 82 boys) who visited the Diabetes Clinic in the Department of Paediatrics, University of Oulu, regularly during 1980 . The age of the subjects was $12.2 \pm 0.3$ years (mean \pm SEM, range 4.0-19.2 years). The mean age at diagnosis of diabetes was 7.4 0.3 years (range $0.9-16.7$ years), whereas the mean duration of the dis- 
Table 1. Serum C-peptide concentrations during 1980 and 24-h urinary C-peptide excretion, mean \pm SEM, in diabetic subjects positive or negative for HLA-D antigens

\begin{tabular}{|c|c|c|c|c|c|c|c|}
\hline \multirow[t]{2}{*}{ HLA antigen } & \multirow{2}{*}{$\begin{array}{l}\text { No. of subjects } \\
+/-\end{array}$} & \multicolumn{2}{|c|}{ Serum C-peptide (nmol/1) } & \multirow{2}{*}{$\begin{array}{l}\text { Level of } \\
\text { significance }\end{array}$} & \multicolumn{2}{|c|}{ Urinary C-peptide $\left(\mathrm{nmol} / \mathrm{m}^{2}\right)$} & \multirow{2}{*}{$\begin{array}{l}\text { Level of } \\
\text { significance }\end{array}$} \\
\hline & & + & - & & + & - & \\
\hline Dwl & $32 / 112$ & $0.11 \pm 0.03$ & $0.06 \pm 0.01$ & NS & $1.85 \pm 0.40$ & $1.00 \pm 0.19$ & NS \\
\hline Dw2 & $2 / 142$ & 0.02 & $0.07 \pm 0.01$ & NS & 0.36 & $1.20 \pm 0.17$ & NS \\
\hline Dw3 & $44 / 100$ & $0.06 \pm 0.01$ & $0.08 \pm 0.01$ & NS & $1.03 \pm 0.37$ & $1.26 \pm 0.19$ & NS \\
\hline Dw4 & $75 / 69$ & $0.07 \pm 0.01$ & $0.08 \pm 0.01$ & NS & $0.94 \pm 0.18$ & $1.47 \pm 0.30$ & NS \\
\hline Dw6 & $13 / 131$ & $0.07 \pm 0.02$ & $0.07 \pm 0.02$ & NS & $0.60 \pm 0.20$ & $1.25 \pm 0.19$ & NS \\
\hline Dw3/Dw4 & $18 / 126$ & $0.03 \pm 0.01$ & $0.09 \pm 0.01$ & $p<0.02$ & $0.27 \pm 0.20$ & $1.34 \pm 0.19$ & $p<0.05$ \\
\hline
\end{tabular}

Table 2. Clinical data and mean $\mathrm{HbA}_{1}$ during 1980 in 18 HLADw3/Dw4 heterozygotes, mean $\pm S E M$, and in 126 other diabetic subjects

\begin{tabular}{|c|c|c|c|}
\hline & \multicolumn{2}{|l|}{ Dw3/Dw4 } & \multirow{2}{*}{$\begin{array}{l}\text { Level of } \\
\text { signifi- } \\
\text { cance }\end{array}$} \\
\hline & + & - & \\
\hline No of subjects & 18 & 126 & \\
\hline Age at diagnosis (years) & $6.4 \pm 1.1$ & $7.6 \pm 0.4$ & NS \\
\hline $\begin{array}{l}\text { Duration of diabetes } \\
\text { (years) }\end{array}$ & $4.6 \pm 0.9$ & $4.7 \pm 0.4$ & NS \\
\hline $\begin{array}{l}\text { Duration of clinical } \\
\text { remission (days) }\end{array}$ & $113 \pm 47$ & $203 \pm 22$ & $p<0.05$ \\
\hline $\begin{array}{l}\text { Daily insulin dose } \\
(\mathrm{U} / \mathrm{kg})\end{array}$ & $0.78 \pm 0.06$ & $0.73 \pm 0.02$ & NS \\
\hline Mean $\mathrm{HbA}_{1}(\%)$ & $14.8 \pm 0.5$ & $13.7 \pm 0.2$ & $p<0.05$ \\
\hline
\end{tabular}

ease was $4.7 \pm 0.3$ years (range $0.1-15.0$ years). The prospective study comprised all the 44 children ( 24 boys) who were admitted to our department from May 1979 to June 1981 for initial treatment of Type 1 diabetes. Their mean age at diagnosis was $9.4 \pm 0.7$ years (range $0.7-16.7$ years). These subjects were observed for the initial 2 years.

All children were seen regularly in the Diabetes Clinic at intervals of 1 to 3 months. The aim of the treatment of the patients was clinical well-being, the absence of diabetic symptoms, normal growth and an optimal metabolic control. Treatment consisted of highly purified insulin once or usually twice daily, a regulated diet and the recommendation of regular physical exercise.

In the cross-sectional study a venous blood sample for the assay of serum C-peptide and blood glycosylated haemoglobin $\mathrm{A}_{1}\left(\mathrm{Hb}_{1}\right)$ was obtained at every visit to the Diabetes Clinic. An individual mean serum C-peptide and mean $\mathrm{HbA}_{1}$ were calculated on the basis of all determinations ( $n=2-8 /$ subject) from each subject during 1980 . The patients were studied in the postprandial state between $10.00 \mathrm{~h}$ and $12.00 \mathrm{~h}$ (i. e. between breakfast and lunch). In addition, a 24 -h urine sample was collected once from the subjects for the measurement of urinary C-peptide excretion. In the prospective study the first sample for the determination of serum $\mathrm{C}$-peptide concentration and $\mathrm{HbA}_{1}$ level was taken before the initiation of the insulin therapy. The following two samples were taken 10 days and 3 weeks after the commencement of insulin therapy in the morning before insulin injection and subsequently every 3 months from diagnosis at visits to the Diabetes Clinic. A blood sample $(10 \mathrm{ml})$ was obtained once in heparinized tubes from all subjects for HLA-typing.

Clinical remission was defined as that period which occurs shortly after the diagnosis of diabetes when the daily insulin requirement is smaller than $0.5 \mathrm{U} / \mathrm{kg}$ and glucosuria is absent or minimal $(<5 \%$ of the carbohydrates in the recommended diet), and which lasts for at least 1 month [11].

\section{Methods}

Serum C-peptide concentrations were analyzed according to Heding [12] using antiserum M 1230 (Novo Research Institute, Bagsvaerd, Denmark). Antibody-bound proinsulin was separated from C-pep- tide by polyethylene glycol before the assay [13]. The sensitivity of the assay was $0.02 \mathrm{nmol} / \mathrm{I}$ and the interassay coefficient of variation $10 \%$. Urinary C-peptide was quantified by the same method in samples diluted $1: 20$. If necessary, the assay was repeated in more $(1: 40)$ or less $(1: 10)$ diluted samples. Accordingly the sensitivity of the urinary $\mathrm{C}$ peptide assay was $0.2 \mathrm{nmol} / 1$. The $24-\mathrm{h}$ urinary C-peptide excretion was expressed in relation to the body surface area. The reference range of 24-h urinary C-peptide excretion in our laboratory was $4.5-17.0 \mathrm{nmol} / \mathrm{m}^{2}$ in non-diabetic children. $\mathrm{HbA}_{1}$ levels were measured by ion-exchange chromatography using a modification of the method described by Welch and Boucher [14]. The reference range in nondiabetic children was $7.0-10.2 \%$, with a mean \pm SEM of $8.6 \pm$ $0.1 \%$. Eight HLA antigens in the A locus (A1, 2, 3, 9, 10, 11, w19 and $28), 16$ in the B locus $(B 5,7,8,12,13,14,15, w 16,17,18$, w21, w22, 27, w35, 37 and 40) and four in the C locus (Cw1, w2, w3 and w4) were determined by the standard two-stage microlymphocytotoxicity test. HLA-D typing was done with local homozygous typing cells defining specificities Dw1, w2, w3, w4 and w6 [15].

\section{Statistical analysis}

The data were statistically evaluated by cross-tabulation and the Fisher exact probability test or chi-square statistics, by the Student's t-test in the case of normally distributed variables and the Mann-Whitney U-test in the case of unequal distribution. The results are expressed as mean \pm SEM.

\section{Results}

Eighty-eight children $(61.1 \%)$ in the cross-sectional study had a mean serum C-peptide concentration higher than the detection limit. The mean of individual mean serum C-peptide concentrations was $0.07 \pm$ $0.01 \mathrm{nmol} / 1$ (range $0.00-0.47 \mathrm{nmol} / 1$ ). The urinary Cpeptide excretion exceeded the detection limit in 87 patients $(60.4 \%)$. The mean $24-\mathrm{h}$ urinary C-peptide excretion was $1.19 \pm 0.17 \mathrm{nmol} / \mathrm{m}^{2}$ (range $0.00-15.11 \mathrm{nmol} /$ $\mathrm{m}^{2}$ ). The urinary C-peptide excretion was within the reference range of nondiabetic children in 13 diabetic children $(9.0 \%)$. The 24-h urinary C-peptide excretion correlated strongly with the mean serum C-peptide concentration $(r=0.79 ; p<0.001)$. There was no relationship between mean serum C-peptide concentrations or 24-h urinary $\mathrm{C}$-peptide excretion and any particular HLA antigen in the A, B or C locus (data not shown). The presence of a single high risk antigen in the $D$ locus did not affect the residual B cell function (Table 1). However, the Dw3/Dw4 heterozygotes had both a decreased mean serum $\mathrm{C}$-peptide concentration and a 


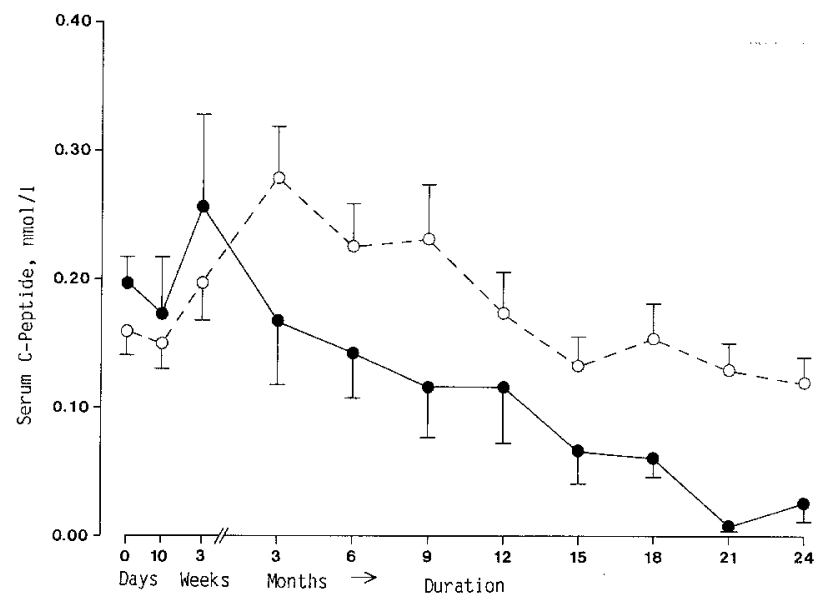

Fig. 1. Serum C-peptide concentrations (mean \pm SEM) over the initial two years in 6 HLA-Dw3/Dw4 heterozygous diabetic children (-) and in 38 children without the Dw3/Dw4 combination $(O--O)(p<0.01$ at 21 months; $p<0.05$ at 24 months for children without the Dw3/Dw4 combination)

lower urinary C-peptide excretion than the other subjects.

The subsequent analysis of characteristics of the clinical course and metabolic control in Dw3/Dw4 heterozygotes showed that there were no significant differences in the age at clinical manifestation of diabetes or in the duration of the disease between the Dw3/Dw4 heterozygotes and the other diabetic children (Table 2). The daily insulin dose was of the same magnitude in both groups. On the other hand, the Dw3/Dw4 heterozygotes had a shorter clinical remission and a higher mean $\mathrm{HbA}_{1}$ level during 1980 than those who carried one or no high risk D antigen.

In the prospective study the serum C-peptide concentrations were of the same magnitude in the Dw3/Dw4 heterozygotes and in the other subjects at clinical manifestation and during the first month after diagnosis (Fig.1). However, the B-cell function started to decline in those with the Dw3/Dw4 combination after 3 weeks, whereas the C-peptide peak occurred more than two months later in the other children. Subsequently the Dw3/Dw4 heterozygotes had lower serum C-peptide levels; from 21 months onwards the endogenous insulin secretion was significantly decreased (21 months: $p<0.01 ; 24$ months: $p<0.05$ ) in the Dw3/Dw4 heterozygotes in comparison with the other patients.

None of the six Dw3/Dw4 heterozygous patients had ketoacidosis at onset, whereas 24 out of the 38 Dw3/Dw4 nonheterozygotes $(p<0.01)$ were ketoacidotic at diagnosis. The daily dose of exogenous insulin was lower in the children with the Dw3/Dw4 combination during the initial treatment (day 1: $0.53 \pm 0.06$ vs. $1.27 \pm 0.12 \mathrm{U} / \mathrm{kg} ; p<0.05$ and day $10: 0.34 \pm 0.06$ vs. $0.55 \pm 0.04 ; p<0.05$ ) than in the remaining subjects. On the contrary, the daily insulin dose was higher at 21 months' duration in the Dw3/Dw4 heterozygotes
$(0.69 \pm 0.08$ vs. $0.53 \pm 0.01 \mathrm{U} / \mathrm{kg} ; p<0.05)$ than in the other children. The individuals with the Dw3/Dw4 combination had a lower $\mathrm{HbA}_{1}$ level at diagnosis $(13.7 \pm 0.3$ vs. $17.7 \pm 0.6 \% ; p<0.05)$ and 10 days later $(12.7 \pm 0.7$ vs. $15.5 \pm 0.4 \% ; p<0.05)$ when compared with the other subjects. Subsequently no significant differences were seen in the $\mathrm{HbA}_{1}$ levels between the two groups.

In the prospective series, the Dw3/Dw4 heterozygotes had a younger age, $6.7 \pm 2.5$ years, at diagnosis than those without the Dw3/Dw4 combination, $9.8 \pm$ 0.7 years, although the difference was not statistically significant. However, the proportion of children under 5 years of age at clinical manifestation was higher among the Dw3/Dw4 heterozygotes than among the other diabetic children $(p<0.02)$.

\section{Discussion}

This study provides evidence for the existence of a distinct form of Type 1 diabetes in childhood associated with Dw3/Dw4 heterozygosity. Our observations indicate that this form is characterized by a reduced residual B-cell function, a clinical remission of short duration and a particularly impaired metabolic control. The prospective study suggests that the reduced B-cell function in Dw3/Dw4 heterozygotes is a consequence of an accelerated B-cell destruction during the initial course of the disease.

The mechanisms behind the low endogenous insulin secretion in Dw3/Dw4 heterozygotes remain to be defined. Our results are compatible with the hypothesis of an aggregation of diabetogenic factors in $\mathrm{D}(\mathrm{R}) 3 / \mathrm{D}(\mathrm{R}) 4$ heterozygotes. The subjects with this combination are known to carry an increased relative risk of diabetes even when compared to homozygotes with $\mathrm{D}(\mathrm{R}) 3$ or $\mathrm{D}(\mathrm{R}) 4[5,16,17]$. There is also a more common occurrence of $D(R) 3 / D(R) 4$ heterozygotes in familial cases and among those of a young age at diagnosis $[16,18]$. The higher risk of these heterozygotes may be due to an exaggerated vulnerability of their B cells to various damaging agents, which after the manifestation of overt diabetes can be reflected in a more rapid destruction process of the $B$ cells.

In a previous study Ludvigsson et al. [19] found a tendency towards a decreased incidence of detectable serum C-peptide concentrations in diabetic children with the HLA-B8/B15 combination. Since Dw3 and Dw4 are in linkage disequilibrium with B 8 and B 15, our findings substantiate their observations. On the other hand, the present results are contradictory to those of Hoogwerf et al. [8], who reported a positive association between HLA-DR4 and residual B-cell function. This may be due to the fact that insulin antibody-bound proinsulin was not removed from the serum samples before the assay of C-peptide in that study. The potential significance of this drawback is emphasized by their 
concomitant observation of increased insulin antibody levels in DR4 positive subjects. Another possible explanation to the conflicting results is that we studied Dw antigens defined by homozygous typing cells, whereas serologically defined DR antigens were determined in the other study. Bach et al. [20] observed in a recent study a considerably increased frequency of Dw4 in DR4 positive diabetic patients as compared with controls. They concluded that Type 1 diabetes may be more closely related to the Dw than to the DR antigens. Similarly Sheehy et al. [21] showed in another report that a particular subset of the DR4 antigen, called "DR4S", accounts for all or at least most of the DR4 association in Type 1 diabetes. Those observations as well as our present results suggest that that $\mathrm{Dw}$ typing may be more discriminating than DR typing in the analysis of the genetic and clinical heterogeneity of Type 1 diabetes.

In the cross-sectional series of the present study there was no significant difference in the mean age at diagnosis between the Dw3/Dw4 heterozygotes and the other subjects whereas the proportion of young children was increased among the Dw3/Dw4 heterozygotes in the prospective series. The latter observation is in agreement with the age distribution in a larger series of Finnish diabetic children [22]. In previous studies [23-25], an early age at the clinical manifestation of diabetes has been shown to be a factor with a negative effect on the residual B-cell function. This could be a consequence of a greater number of subjects with the Dw3/Dw4 combination and accordingly an accentuated vulnerability of their B cells in the young age groups. On the other hand, it must be noted that a diabetogenic insult at an early age may eliminate the subsequent growth of the B-cell mass, the absolute amount of which increases fourfold from infancy to adulthood in nondiabetic individuals [26].

In the prospective series the Dw3/Dw4 heterozygous children had a milder metabolic decompensation at the clinical onset of diabetes. This explains at least partly why the Dw3/Dw4 heterozygotes managed with significantly less exogenous insulin than the other patients over the initial 10 days. Previous observations [23, 27] that a more intensive initial insulin treatment can result in a prolonged preservation of the residual B-cell function and a clinical remission of longer duration, may to some extent be due to an over-representation of Dw3/Dw4 nonheterozygotes among those patients who initially need high insulin doses for the correction of the metabolic derangements at diagnosis but later have a milder clinical course.

Our results give further support to the concept of heterogeneity of 'Type 1 diabetes and focus attention on the need to differentiate the distinct forms of the disease in research on the aetiology, pathogenesis as well as the natural history of diabetes. The present evidence of a clinically more severe course in the initial phase of diabetes in Dw3/Dw4 heterozygous children is a challenge to further studies on the possible relation between
Dw3/Dw4 heterozygosity and the long-term prognosis of the disease. In a study on monozygotic twins, Nelson and Pyke [28] found that the concordant pairs developed diabetic complications more frequently and severely than the discordant pairs and that the B8/B15 combination was over-represented among the concordant twins. Their observations indicate that Dw3/Dw4 heterozygosity may also be related to the long-term complications of Type 1 diabetes. Finally, the present findings may have implications for the treatment of children with Type 1 diabetes; the subjects with the "unfortunate" Dw3/Dw4 combination will need particularly efficient therapeutic measures to have a better chance of coping with their disease.

Acknowledgements. We thank Ms. S. Anttila and Mr. M. Vuoti for excellent technical assistance. This study was supported by grants from the Alma and K.A.Snellman Foundation, Oulu, Finland (MK) and Novo Research Institute, Bagsvaerd, Denmark.

\section{References}

1. Svejgaard A, Platz P, Ryder LP, Staub-Nielsen L, Thomsen M (1975) HL-A and disease associations - a survey. Transplant Rev 22: 3-43

2. Nerup J, Platz P, Ryder LP, Thomsen M, Svejgaard A (1978) HLA, islet cell antibodies and types of diabetes mellitus. Diabetes 27 (Suppl 1): 247-250

3. Svejgaard A, Ryder LP (1981) HLA genotype distribution and genetic models of insulin-dependent diabetes mellitus. Ann Hum Genet 45: 293-298

4. Rotter JI, Anderson CE, Rubin CR, Congleton JE, Terasaki PI, Rimoin DL (1983) HLA genotypic study of insulin-dependent diabetes. The excess of DR3/DR4 heterozygotes allows rejection of the recessive hypothesis. Diabetes $32: 169-174$

5. Wolf E, Spencer KM, Cudworth AG (1983) The genetic susceptibility to type 1 (insulin-dependent) diabetes: Analysis of the HLADR association. Diabetologia 24:224-230

6. Rotter JI, Rimoin DL (1981) Genetics of insulin-dependent diabetes mellitus. In: Martin JM, Ehrlich RM, Holland FJ (eds) Etiology and pathogenesis of insulin-dependent diabetes mellitus. Raven Press, New York, pp 37-59

7. Madsbad S (1983) Prevalence of residual B cell function and its metabolic consequences in Type 1 (insulin-dependent) diabetes. Diabetologia 24: 141-147

8. Hoogwerf BJ, Rich SS, Barbosa J (1985) Meal stimulated C-peptide and insulin antibodies in type 1 diabetic subjects and their nondiabetic siblings characterized by HLA-DR antigens. Diabetes $34: 440-445$

9. Canivet B, Harter M, Viot G, Balarac N, Krebs BP (1980) Residual beta-cell function in insulin-dependent diabetics: evaluation by circadian determination of C-peptide immunoreactivity. J Endocrinol Invest 3: 107-111

10. Buschard K, Madsbad S, Rygaard J (1982) Suppressor cell activity in patients with newly diagnosed insulin-dependent diabetes mellitus. A prospective study. J Clin Lab Immunol 8: 19-23

11. Knip M, Säkkinen A, Huttunen N-P, Käär M-L, Länkelä S, Mustonen A, Åkerblom HK (1982) Postinitial remission in diabetic children: an analysis of 178 cases. Acta Paediatr Scand 71: 901-908

12. Heding LG (1975) Radioimmunological determination of human C-peptide in serum. Diabetologia 11: 541-548

13. Kuzuya H, Blix PM, Horwitz DL, Steiner DF, Rubenstein AH (1977) Determination of free and total insulin and C-peptide in insulin-treated diabetics. Diabetes 26: 22-29 
14. Welch SG, Boucher BJ (1978) A rapid micro-scale method for the measurement of hemoglobin $A_{1(a+b+c)}$. Diabetologia 14: 209-211

15. Ilonen J, Reunanen M, Salmi A, Tiilikainen A (1981) Lymphocyte blast transformation responses and viral antibodies in relation to HLA antigens in multiple sclerosis. J Neurol Sci 49: 117-133

16. Svejgaard A, Platz P, Ryder LP (eds) 1980 Joint report - insulindependent diabetes. In: Terasaki PI (ed) Histocompatibility testing. UCLA Tissue Typing Laboratory, Los Angeles, pp 638-656

17. Platz P, Jacobsen BK, Morling N, Ryder LP, Svejgaard A, Thomsen M, Christy M, Kromann H, Benn J, Nerup J, Green A, Hauge $M$ (1981) HLA-D and -DR antigens in genetic analysis of insulindependent diabetes mellitus. Diabetologia 21: 108-115

18. Johnston C, Pyke DA, Cudworth AG, Wolf E (1983) HLA-DR typing in identical twins with insulin-dependent diabetes mellitus: difference between concordant and discordant pairs. Br Med J 286: $253-255$

19. Ludvigsson J, Säfwenberg J, Heding LG (1977) HLA-types, Cpeptide and insulin antibodies in juvenile diabetes. Diabetologia 13: 13-17

20. Bach FH, Rich SS, Barbosa J, Segall M (1985) Insulin-dependent diabetes - associated HLA-D region encoded determinants. Hum Immunol 12: 59-64

21. Sheehy MJ, Rowe JR, MacDonald MJ (1985) A particular subset of HLA-DR4 accounts for all or most of the DR4 association in type 1 diabetes. Diabetes 34: 942-944

22. Mustonen A, Ilonen J, Tiilikainen A, Kataja M, Åkerblom HK (1985) An analysis of epidemiological data in HLA-typed diabetic children. Diabetologia 28: 397-400

23. Ludvigsson J, Heding LG, Larsson Y, Leander E (1977) C-peptide in juvenile diabetics beyond the postinitial remission period: rela- tion to clinical manifestations at onset of diabetes, remission and diabetic control. Acta Paediatr Scand 66: 177-184

24. Menchini M, Meschi F, Lambiase R, Puzzovio M, Del Guercio MJ, Chiumello G (1980) C-peptide response to arginine stimulation in diabetic children. J Paediatr 96:362-366

25. Knip M, Puukka R, Käär M-L, Åkerblom HK (1982) Remission phase, endogenous insulin secretion and metabolic control in diabetic children. Acta Diabetol Lat 19:243-251

26. Rahier J, Wallon J, Henquin JC (1981) Cell populations in the endocrine pancreas of human neonates and infants. Diabetologia 20: $540-546$

27. Mirouze J, Selam JL, Pham TC, Mendoza E, Orsetti A (1978) Sustained insulin-induced remission of juvenile diabetes by means of an external artificial pancreas. Diabetologia 14: 223-227

28. Nelson PG, Pyke DA (1976) Diabetic complications in concordant identical twins. In: Creutzfeld W, Köbberling J, Neel JV (eds) Genetics of diabetes mellitus. Springer, Berlin Heidelberg New York, pp 215-233

Received: 26 November 1985

and in revised form: 21 April 1986

Dr. Mikael Knip

Department of Paediatrics

University of Oulu

SF-90220 Oulu

Finland 